\title{
Autoevaluace jako nástroj pro podporu a rozvoj skautských oddílů
}

\author{
Self-evaluation as a tool for support and growth of scout units \\ Anna Šlechtová
}

\begin{abstract}
Abstrakt: Příspěvek představuje strukturu a proces tvorby autoevaluačního dotazníku pro skautské oddíly z organizace Junák - svaz skautů a skautek ČR. Východiskem pro definování standardu kvality byl obecný model kvality (Starý a Chvál, 2009). Při tvorbě autoevaluačního dotazníku byla akcentována participace všech aktérů hodnocení, jeho pravidelné jednoroční opakování a rozvojová perspektiva dotazníku, který kromě zhodnocení stavu zároveň ukazuje, jak je možné se zlepšit. V současné chvíli probíhá dvojí testování těchto dotazníků.
\end{abstract}

Klíčová slova: autoevaluační dotazník, evaluace, kvalita, skaut, standard kvality

\begin{abstract}
This text presents the structure and process of creating self-evaluation questionnaire for scout units from Junák - Association of Scouts and Guides of the Czech Republic. The basis for definition of quality standard was general quality model by Starý and Chvál (2009). While forming the questionnaire, participation of all people involved in the evaluation, its annual repetition and prospect of further development of the questionnaire (which besides evaluating current state also shows ways of improvement) were emphasized. Two ways of testing the questionnaire are currently taking place.
\end{abstract}

Keywords: evaluation, quality, quality standard, scout, self-evaluation questionnaire

\section{1 Úvod}

Podobně jako je $\mathrm{v}$ současnosti věnována velká pozornost standardům kvality v oblasti formálního vzdělání, vyvstává otázka definování standardů kvality a potřeba autoevaluačních nástrojů i v organizacích věnujících se pedagogice volného času. Mezi nimi Junák - svaz skautů a skautek ČR si v roce 2008 stanovil jako svoji strategickou prioritu „Kvalitu oddílové činnosti““. V návaznosti na toto rozhodnutí se začalo pracovat na prípravě autoevaluačního nástroje, který by pomohl zjistit, jaká je kvalita oddílové činnosti a zároveň byl odrazovým můstkem pro její zlepšování.

Cílem článku je představit proces tvorby autoevaluačního dotazníku, jehož výstupy budou použity pro následné analýzy kvality oddílové činnosti v hnutí, naznačit všechny kontrolní mechanismy, které jeho tvorbu provázeli a tím dokázat jeho validitu. 


\title{
2 Vymezení základních pojmů
}

\author{
- Kvalita
}

Starý a Chvál (2009) shrnují ve shodě s Průchou (1996), že pojem kvalita je v pedagogické oblasti používán ve dvou významech: (1) jako obecný pojem pro výraz pozitivní či negativní míry dosažené úrovně (procesu či výstupu) a za (2) pro vyjádření stavu, který je optimální, žádoucí, ideální, tedy a priori pozitivní. V praxi se oba významy překrývají a nezřídka se používají souběžně. Zde budeme pracovat s druhým uvedeným významem.

- Standard kvality

Je konkrétním vyjádřením kvality, která je definována sumou indikátorů odpovídající úrovně.

\section{- Kritérium}

Lze definovat jako určitý znak, hledisko, charakteristiku či vlastnost sledovaného (Šustová, 2009), na základě které lze hodnotit jeho kvalitu.

\section{- Indikátor/úroveň kritéria}

Ukazatel dosažení daných cílů (Starý \& Chvál, 2009) či-li kvality. Obdobně jinými slovy definuje indikátory Rýdl (2010), který jej chápe jako operacionalizované kritérium, které umožňuje hodnocení sledovaného jevu.

\section{Východiska}

Pedagogická evaluace se v posledních letech živě rozvíjí v teoretické i praktické rovině. Značná část pozornosti je věnována hodnocení ${ }^{1}$ kvality $^{2}$. Starý a Chvál (2009) představují obecný model kvality, který znázorňují ve tvaru pyramidy (Obrázek 2), jejíž základ tvoří 1) indikátory nad ní stojí 2) specifické cíle (subkritéria), 3) cíle (kritéria), 4) podoblasti kvality a 5) na samém vrcholu stojí oblasti kvality. S tím, že při plánování se postupuje od vrcholu tedy od obecnější oblastí kvality ke konkrétním indikátorům naopak při hodnocení se vychází $\mathrm{z}$ dosažených indikátorů $\mathrm{k}$ hodnocení $\mathrm{v}$ jednotlivých oblastech. Podle stejného modelu, ale $\mathrm{s}$ využitím upravené terminologie je postaven i model Hodnocení kvality (dále HK) ${ }^{3} \mathrm{v}$ Junáku - svazu skautů a skautek ČR (dále Junák). Vztah obou modelů je znázorněn na obrázku 1.

Podle současných trendů v evaluaci (podle Pol \& Erčulj, 2010) je akcentována rozvojová perspektiva evaluace, což znamená, že na evaluaci př́mo navazuje snaha o změny, které jsou evaluací podloženy. Dále Pol a Erčulj (2010) uvádějí přechod od jednorázového hodnocení $\mathrm{k}$ procesuálnosti, čili procesu s řadou fází a cyklickým charakterem oproti př́ležitostnému provádění hodnocení. Další trend podle výše uvedených autorů vede k participativní evaluaci, která znamená zapojení hodnocených do téměř všech fází evaluace (od diskuse nad účelem, cíli, přes stanovení kritérií kvality po plánování postupu hodnocení) a uvádějí, že v takovém př́padě je rozvoj a změna po evaluaci významnější. Všechny výše uvedené trendy rozvojová perspektiva evaluace, procesuálnost a participace byly využity jako východiska při tvorbě autoevaluačního dotazníku v rámci HK.

\footnotetext{
${ }^{1}$ Pojem hodnocení a evaluace používáme v tomto textu jako synonyma i při vědomí probíhající diskuse o vymezení těchto pojmů.

${ }^{2}$ Např. v rámci projektu Cesta ke kvalitě realizovaným Národním ústavem odborného vzdělávání.

${ }^{3}$ Hodnocení kvality (dále HK) je projekt realizovaný Junákem - svazem skautů a skautek ČR, který má za cíl podpořit a zmapovat kvalitu základních výchovných jednotek organizace - skautských oddílů a zároveň jim nabídnout podporu.
} 

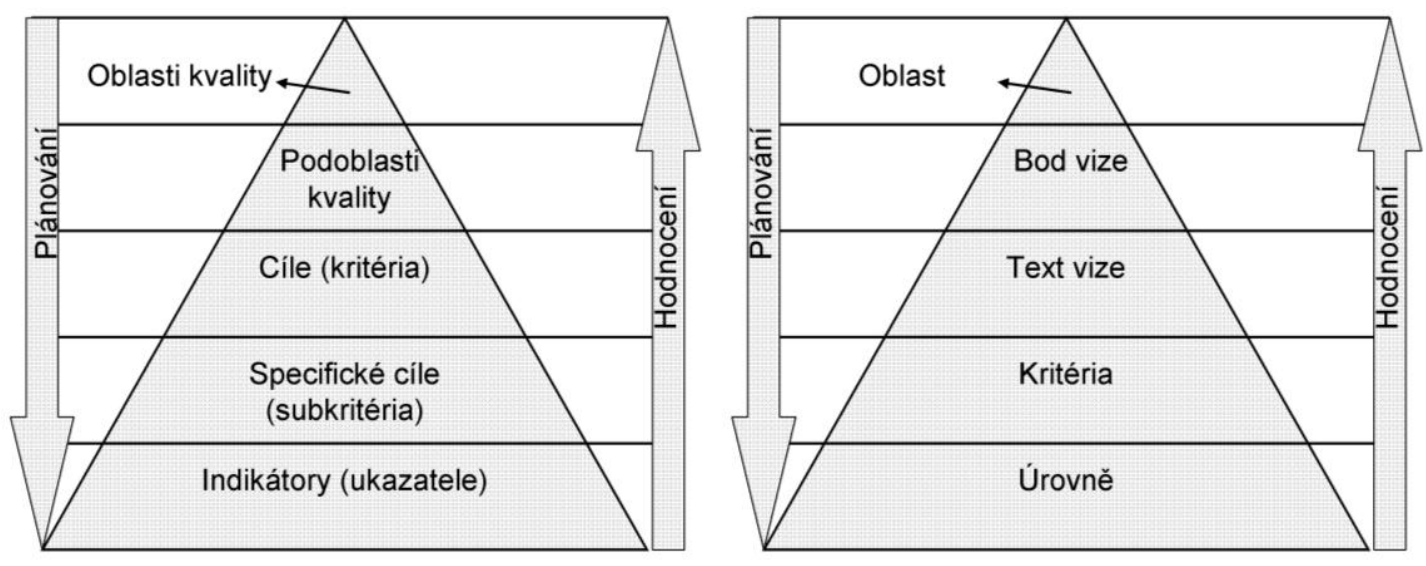

Obrázek 1. Vlevo obecný model kvality podle Starý a Chvál (2009), vpravo odpovídající model kvality s pojmoslovím používaným při hodnocení kvality oddílů. Pojmy na jednotlivých hladinách si významově odpovídají. Pojmy na stejné hladině jsou proto v dalším textu používány jako synonyma.

\section{Postup tvorby autoevaluačního dotazníku}

Celý proces tvorby standardů kvality, tedy hledání odpovědi na otázku co to znamená kvalitní oddíl, byl otevřený a založený na možnosti participace všech aktérư ${ }^{4}$. Důležitým požadavkem bylo aby autoevaluační nástroj ukazoval, kam jít dál, tedy aby měl rozvojovou perspektivu. Dalším požadavkem bylo opakování hodnocení v jednoročním cyklu, z čehož vyplynulo, že se většina indikátorů vztahuje k období jednoho roku, tímto byl naplněn princip procesuálnosti, tj. zamýšleného cyklického opakování. Vytvořený standard kvality je základem autoevaluačního dotazníku - tvoří ho čtvrtá nejvyšší úroveň kritérií. Proces tvorby standardu kvality i ukázka části autoevaluačního dotazníku je znázorněna na obrázku 2. Stručný popis k jednotlivým fázím je uveden v textu níže.

\section{1) Definování kritérií kvality}

V prvním kroku byla definována kritéria kvalita expertním způsobem tj. skupinou cca 9 lidí a doplněna na základě dalších pramenů. Při definování kritérií jsme vycházeli ze Stanov Junáka ${ }^{5}$, Strategie Junáka ${ }^{6}$ a materiálů zahraničních národních skautských organizací, které již měly vytvořený standard kvality včetně nástroje pro hodnocení kvality, inspirativní byl zejména velmi podrobný belgický materiál ${ }^{7}$ dále slovenský ${ }^{8}$ a irský ${ }^{9}$. Začátek na této úrovni se osvědčil, jelikož kritéria jsou sama o sobě velmi dobře uchopitelná.

\footnotetext{
${ }^{4}$ Všemi aktéry jsou míněni jak vůdci oddílů a jejich spolupracovníci, tak lidé z vyšších organizačních jednotek, členové odborných odborů při ústředí Junáka, náčelnictvo atd.

${ }^{5}$ Stanovy Junáka platné z 21. 10. 2001.

${ }^{6}$ Strategie Junáka - svazu skautů a skautek ČR do roku 2005.

${ }^{7}$ Le plan USO, 2002.

${ }^{8}$ Zmerajte si kvalitu svojho oddielu [online]. 2005-2009. Dostupný z

<http://www.scouting.sk/scouting/aktuality/1178-zmerajte-si-kvalitu-svojho-oddielu.html>.

${ }^{9}$ Scout Group Supporting Quality Scouting for Young People, 2006.
} 
2) Vytvoření bodů vize ${ }^{10}$

Jednotlivá kritéria byla roztříděna a rozdělena do jednotlivých podoblastí, které byly nazvány souhrnným názvem, dále o těchto podoblastech mluvíme jako o bodech vize (viz obrázek 1).

3) Definování cíle/textu vize

Body vize byly formulovány do jasného vyjádření v podobě věty či souvětí, tak aby zahrnovala všechna kritéria, která se k dané vizi vztahují. Kontrola byla provedena i v opačném směru, zda vše co je vyjádřeno vizí, je dále operacionalizováno do podoby kritérií.

4) Připomínkování vizí

$\mathrm{V}$ tomto kroku byly cíleně osloveni někteří členové hnutî ${ }^{11} \mathrm{k}$ přímému připomínkování. Dále bylo otevřeno široké připomínkování pro všechny členy hnutí. Pro další práci na projektu byla nutná shoda na bodech vize i jejich textovém znění. Na základě připomínek k vizi byla přepracována i kritéria.

5) Vize seskupena do oblastí

Jednotlivé body vize byly rozděleny do pěti oblastí, které jsou jednotné např́č hodnocením všech jednotek v Junáku. Jedná se následující oblasti: Lidé, Řízení a plánování, Program a činnost, Působení navenek a Zázemí. Zároveň byla dopracována kritéria na základě připomínek vzešlých z prvního připomínkování.

6) Definování úrovní kritérií (indikátorů)

Všechna kritéria byla rozpracována do čtyř úrovní - viz obrázek 2. Indikátory ve čtvrté úrovni odpovídají standardu kvality. Jednotlivé úrovně odpovídají stavu hodně slabý - slabý - dobrý - velmi dobrý.

7) Připomínkování úrovní (indikátorů)

Proběhla druhé otevřené prripomínkování, při kterém bylo získáno více jak 100 konkrétních připomínek.

8) Převedení standardů kvality do formy dotazníku a testování

Zásadním momentem pro ověření validity je testování. Testování probíhá od června 2011 do ř́jjna 2011. Probíhají dva typy testování. (1) Do širokého testování se mohou přihlásit všechny jednotky, předávají výsledky hodnocení a zpracovávají hodnotící zprávu, ve které jsou i položky vztahující se k validitě dotazníku. (2) Je prováděno tzv. zacílené testování, do kterého byly cíleně vybrány jednotky podle věku vůdce, délky vedení tímto vůdcem, velikosti oddílu, typu vedení (jednotlivec vs. tým), organizační struktury, podle vztahu k novým výchovným nástrojům a podle typu sídla (vesnice, maloměsto, velkoměsto), tak aby byly zastoupeny všechny jednotky. Zacíleného testování se kromě týmu vedení účastní jeden externí pozorovatel a dále někdo, kdo jednotku zná, ale není členem aktivního vedení. Při zacíleném testování je kromě validity ověřována i reliabilita dotazníku.

\footnotetext{
${ }^{10}$ Pojem vize je užíván s ohledem na prostředí, ve kterém je dotazník tvořen i pro koho je určen. Skautští činovníci (vůdci) jsou zvyklí pracovat s vizemi při plánování i hodnocení vlastní činnosti.

${ }^{11}$ Členové odborů, náčelnictva, zájemci o projekt.
} 


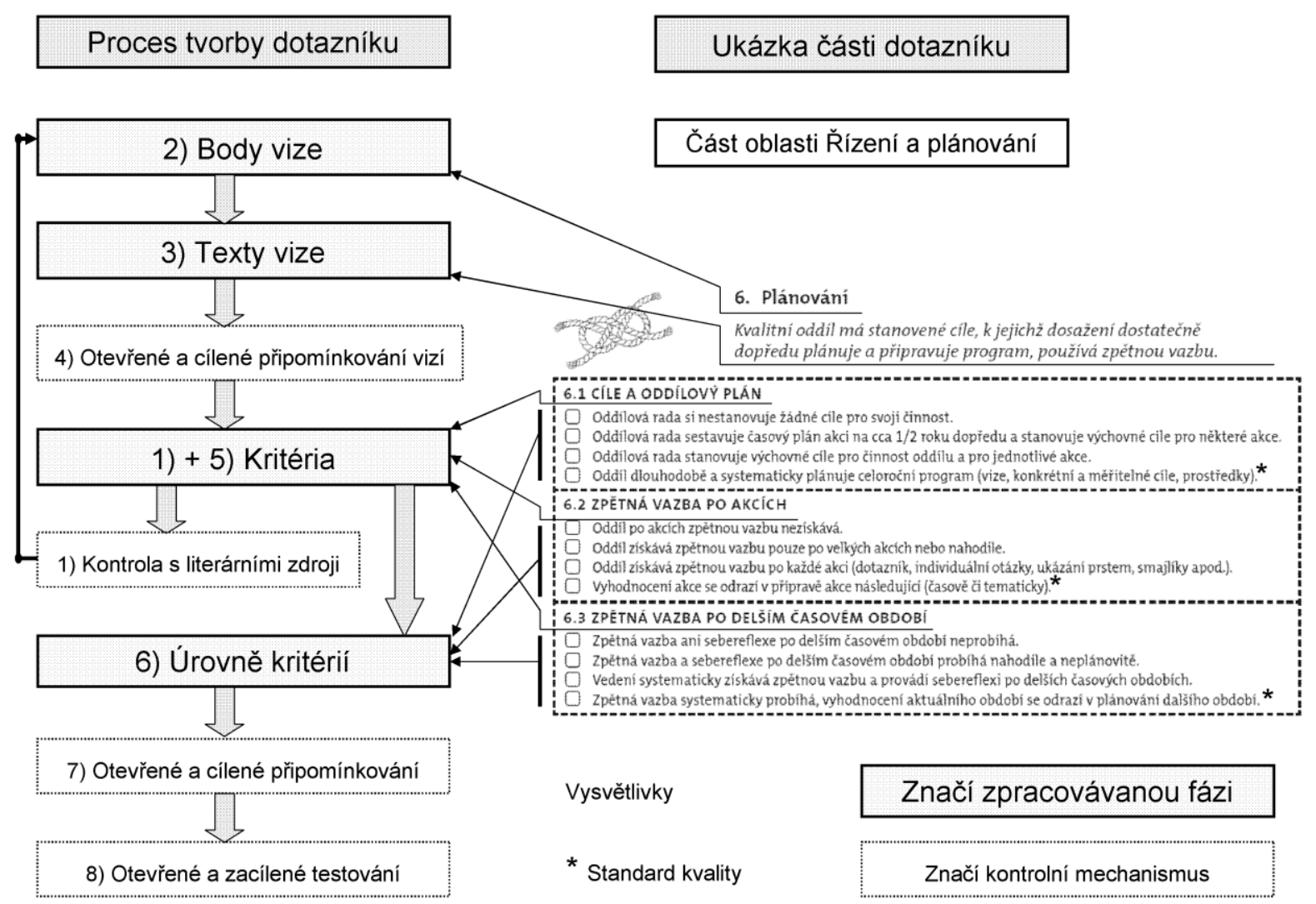

Obrázek 2. Proces tvorby standardu kvality a ukázka konečného výstupu v autoevaluačním dotazníku. Autoevaluační dotazník pro hodnocení kvality oddílů má celkem 63 položek. Čísla ve schématu odpovídají číslům odstavců v textu.

\section{Závěr}

$\mathrm{V}$ př́spěvku byla představena struktura a proces tvorby dotazníku pro autoevaluaci skautských oddílů, který vychází z obecného modelu kvality (Starý \& Chvál, 2009). V současné době je autoevaluační dotazník ve fázi testování, která bude ukončena a vyhodnocena do konce roku 2011.

\section{Poděkování}

Poděkování patří všem členům týmu projektu Hodnocení kvality a zejména Ondřeji Kupkovi, který tým vede.

\section{Literatura}

Le plan USO. (2002). Bruxelles: Fédération catholique des scouts Baden-Powell de Belgique.

Pol, M., \& Erčulj, J. (2010). Trendy v evaluaci práce vedoucích pracovníků škol. Orbis scholae, 4(1), $7-27$.

Průcha, J. (1996). Pedagogická evaluace. Brno: MU.

Rýdl, K. (2010). Ukazatel. Na cestě ke kvalitě. Bulletin projektu Cesta ke kvalitě, 1(2), 8-9. 
Scout Group Supporting Quality Scouting for Young People. (2006). Ireland: Scouting Ireland.

Stanovy Junáka - svazu skautů a skautek C $R$. Schválené X. Valným sněmem Junáka ve Vsetíně dne 21. 10. 2001. Dostupné z http://krizovatka.skaut.cz/organizace/dokumenty/spisovna/detail-105/.

Starý, K., \& Chvál, M. (2009). Kvalita a efektivita výuky: Metodologické př́stupy. In M. Janíková \& K. Vlčková (Eds.), Výzkum výuky (pp.63-81). Brno: Paido.

Strategie Junáka - svazu skauti̊ a skautek $\check{C} R$ do roku 2005. Dostupné z http://krizovatka.skaut.cz/organizace/dokumenty/spisovna/detail-1444/.

Šustová, P. (2009). Kritérium. In Kvalita a hodnocení ve vzdělávání: Výkladový slovník. Praha:

NÚOV. Dostupné z http://slovnik.evaluacninastroje.cz/\#phraseId=75\&phrase=KRITÉRIUM.

\section{Kontakt}

Mgr. Anna Šlechtová

Univerzita Karlova v Praze

Filozofická fakulta, Katedra pedagogiky

Celetná 20, 110 00, Praha 1

e-mail: anna.slechtova@gmail.com

\section{Bibliografické údaje}

Šlechtová, A. (2011). Autoevaluace jako nástroj pro podporu a rozvoj skautských oddílů. In T. Janík, P. Knecht, \& S. Šebestová (Eds.), Smišený design v pedagogickém výzkumu: Sborník př́spěvků z 19. výročni konference České asociace pedagogického výzkumu (s. 228-233). Brno: Masarykova univerzita.

Dostupné z: http://www.ped.muni.cz/capv2011/sbornikprispevku/slechtova.pdf

doi: 10.5817/PdF.P210-CAPV-2012-62 